\title{
EMPOWERMEN FOR WOMEN WHO STAY IN AUSTRALIA IN PARENTING AT MULTICULTURAL CONTEX
}

\author{
Yufiarti, Lara Fridani, Gusti Devi Artanti, Cucu Cahyana, Irma Rosalinda, Fildzah \\ Rudyah Putri \\ Universitas Negeri Jakarta
}

Email:yufiartizein@gmail.com

\begin{abstract}
The aim of current community service is to empower Indonesian women living in Australia in knowledge of multicultural education and care in a multicultural context. The problems faced by Indonesian women living in Australia are very complex, starting with the goal of going to Australia, mobility, educating their children in different cultures to dealing with children's problems and themselves. This service was carried out for two years. The approach taken is to provide parenting training in a multicultural context. The duration to conduct this research will be two years by stages. In the first year of study, the followings processes will take place namely identification, training, counseling and evaluation. Final stages of publication (journals and proceedings). In the second years: (1) recommendation, (2) Focus Group Discussion, and publication. The resulting output is: 1) The implementation of women's empowerment activities in parenting in multicultural context. 2) Multicultural education guidelines for mothers. 3) Certificates for participants who take part in the activity. This study will resulting; a) Published paper in national journal, b) Online media publication, c) Video uploaded on Youtube, and d) Webinar event held in Australia using an online platform. The community service implemented on Junne 2021 followed by 31 members. The activities doing well such Focus Discussion, counseling and evaluation. Based on the result of instrumen the mothers interest on the subject matter. They are sutiesfied of this activities. They need this activities again for other subject such as cooking theme.
\end{abstract}

Keywords: Women empowerment, Parenting in Multicultural Contex

\section{Abstrak}

Tujuan dari pengabdian masyarakat saat ini adalah untuk memberdayakan perempuan Indonesia yang tinggal di Australia dalam pengetahuan tentang pendidikan dan perawatan multikultural dalam konteks multikultural. Masalah yang dihadapi perempuan Indonesia yang tinggal di Australia sangat kompleks, mulai dari tujuan pergi ke Australia, mobilitas, mendidik anak-anaknya dalam budaya yang berbeda hingga menangani masalah anak dan diri mereka sendiri. Pelayanan ini dilakukan selama dua tahun. Pendekatan yang dilakukan adalah dengan memberikan pelatihan parenting dalam konteks multikultural. Durasi untuk melakukan penelitian ini adalah dua tahun secara bertahap. Pada tahun pertama studi, proses berikut akan berlangsung yaitu identifikasi, pelatihan, konseling dan evaluasi. Tahap akhir publikasi (jurnal dan prosiding). Pada tahun kedua: (1) rekomendasi, (2) Focus Group Discussion, dan publikasi. Output yang dihasilkan adalah: 1) Terlaksananya kegiatan pemberdayaan perempuan dalam parenting dalam konteks multikultural. 2) Pedoman pendidikan multikultural bagi ibu. 3) Sertifikat bagi peserta yang mengikuti kegiatan. Penelitian ini akan menghasilkan- a) Publikasi makalah di jurnal nasional, b) Publikasi media online, c) Video yang diunggah di Youtube, dan d) Acara webinar yang diadakan di Australia menggunakan platform online. Pengabdian kepada masyarakat dilaksanakan pada Juni 2021 diikuti oleh 31 anggota. Kegiatan yang dilakukan dengan baik seperti webinar melalui zoom, Focus Discussion, penyuluhan dan evaluasi. Berdasarkan hasil instrumen minat ibu terhadap materi pelajaran. Mereka puas dengan kegiatan ini. Mereka membutuhkan kegiatan ini lagi untuk mata pelajaran lain seperti tema memasak.

Kata kunci: Pemberdayaan Perempuan; Pengasuhan dalam Konteks Multikultural 


\section{INTRODUCTION}

\section{Situation Analysis}

The Australian Department of Education and Training (DFAT) indicated the number of international students coming to Australia has consistently increased from year to year. As presented in the figure 1 below, Australia is the country that accepts the largest number of Indonesian students to study from undergraduate, Masters to Doctoral levels. Based on the World Education Services (2019) data, Australia ranked first as a country destination for Indonesian student study abroad (WES, 2018).

\section{Problems of Mitra}

Base don the condition, the problems of collaborate such as: (1) How empoworment women in parenting in multicultural contex. Despite those high number, there are many problems faced by Indonesians lived in Australia. In particular Indonesia wife who accompanied her husband pursuing study in Australia. This especially those who bring their children to live in Australia. The problem including 1) preparing halal meal for the family, 2) finding religious education services for their children, and 3) preparing children's mental and emotional capacity to adapt with the cultural changes as well maintaining their Indonesian values. These problems need to be addressed properly in order to manage their family values and norms accordance to what they believed. To illustrate this, In the midst of all these difficulties and limitations, Indonesian
Muslim parents in Australia still try to teach their children to have strong religious guidelines. Although they often feel that there are many challenges and difficulties and are limited by various things. They often worry about an environment that is contrary to Muslim culture and way of life. These parents seek various ways with all their limitations so that their children have faith, reason, and strong morals in accordance with the principles of the Islamic religion.

One aspect needs to be considered is that parents need support to educate their children in multicultural environment. The people around the child must be sensitive and responsive parenting. Sensitive means being able to recognize visible signs, interpret these signs appropriately and immediately respond according to the child's emotional needs. For this reason, parents need to apply positive disciplinary methods. No need to hit, get angry or yell. On the other hand, looking at the phenomenon of intolerance in Indonesia recently, multicultural concepts need to be taught to children from an early age. Multicultural education is a way of looking at reality and a way of respecting various religions, ethnicities, races and cultures because God Almighty created it all.

The existence of multicultural education will reduce prejudice or racial traits in children. The school is obliged to create a tolerant school culture, empowering students from various religious, racial, ethnic and cultural groups by creating various school 
programs. But the most important thing is, multicultural education is crucial for preparing children facing the global challenges and environment.

\section{Aim of The Community Services}

This community services aim to help Indonesian women lived in Australia to manage their kids' education using psychological and multicultural perspective. It is expected that this activity will promote a resilience and positive response from the respective participants.

\section{LITERATURE REVIEW}

\section{Solution}

The solution taken to overcome the above problems is to increase knowledge about multicultural education. Multicultural education principles, mother's responsibility, overcoming children's problems, and group counseling processes. Hence, planting multicultural awareness to young children one of which can be done through the family environment. Mother role which most of childhood time going through, will affects in child development of multicultural understanding as a basis of multicultural awareness to early childhood is very large. Indonesian women who live abroad with their family must provide understanding to the children that differences in nation pluralism is a beautiful thing. Australia, such pluralism should be used as a vehicle for unifying the nation, rather than used as a trigger disintegration of the nation. Diversity that would look good, beautiful, harmonious and well balanced when walking

Moms can use the analogy of a rainbow. The unity color of rainbow is beautiful because it supported by variety of colors. Diversity colors make a beautiful rainbow appeared. It would not be possible to look beautiful when the rainbow is composed by only one color. Similarly, the world wide, will be able to be a beautiful thing and fruitfull when composed of cultures, races, religions and different beliefs among united diversity of each other. Mother who forms a large part of the child's time especially when surviving in abroad with their family, also can be showed with the embed of multicultural awareness through song. Songs associated with multicultural awareness such as "lihat kebunku penuh dengan bunga. Ada yang putih, dan ada yang merah. Setiap hari kusiram seтиа. Mawar melati semиаnya indah". From the song "Look at my garden" is then moms need to convey to children that the Indonesian nation is like a garden. Inside there are a variety of race, class, religion and belief. All of them will be beautiful when maintained like a park. Mother can explain that maintain is same like understanding or taking care of the diversity to become the beautiful unity, not exactly the differences are eliminated altogether. Besides, there is a song called Rainbows in Indonesia, "Pelangi-pelangi, alangkah indahmu, merah kuning, hijau, di langit yang biru...". Using the analogy of the song "Look at my garden" and "Rainbow" will planting multicultural awareness to young children through a a 
moms with loving expression will describe family picture which should be an example of a parent.

To remembered that psychological theory of life span development stated that in early life is a golden age which very easy to imitate behaviors performed by those around them. In this case mom need to give examples of how to get along with people of different religions, different habit, different the way of life, and so on. Parents should provide examples of behavior to respect people of different of such pluralisms, for example when there are other people of different religions are running the church, then should not interfere. Besides that, mother must also provide an example for others who do not mocking different languages, and customs. At the point that parents must set an example for not lowering the cultural identity of others who differ with children. Inability to accept these differences without realizing it greatly affects to psychological development of child, which will carry over to the next stage of their life. Therefore, it should not be ignored by parents, especially mothers who are more reliable with their children all the time.
However, planting of multicultural awareness from mother to children is expected to be able to equip our children's lives and enable them to interact with their environment properly. Children is able to accept and appreciate with different ethnic groups, cultures, religions, and beliefs. In addition, children will also be easier and easier adjust themselves socially acceptable environment with parent's support especially from their mom.

\section{Output Type}

The resulting output is: 1) The implementation of women's empowerment activities in parenting in multicultural context. 2) Multicultural education guidelines for mothers. 3) Certificates for participants who take part in the activity

\section{Product}

This study will resulting; a) Published paper in national journal, b) Online media publication, c) Video uploaded on Youtube, and d) Webinar event held in Australia using an online platform.

\section{RESEARCH METHODS}

The following method will apply in this community service activity. 


\section{TRAINING METHOD}

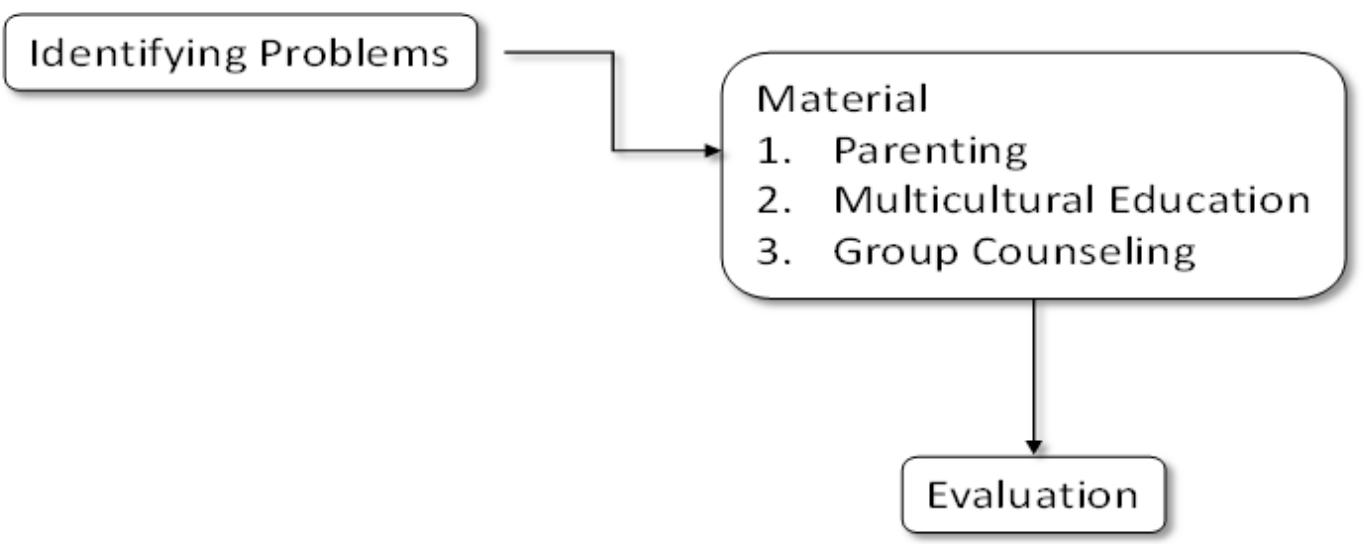

Figure 1. Community Service Plan

Based on the figure 1 above, the training method starts from identifying the problems of mothers living in Australia. Activities carried out by the lecture method, interviews with participants. Based on the first step, it can be concluded that the problems faced by the participants are followed by determining the training materials based on the participants' needs.

The next step is providing material on multicultural and parenting education. The material starts from an understanding of the principles of multicultural education.

Furthermore, group counseling is carried out with various problems that have been grouped. Develop joint recommendations, practice in educating children in minorities. Furthermore, a training evaluation is carried out. Assessment of the benefits of training and increasing knowledge about multiculturalism. 


\section{RESULT AND DISCUSSION}

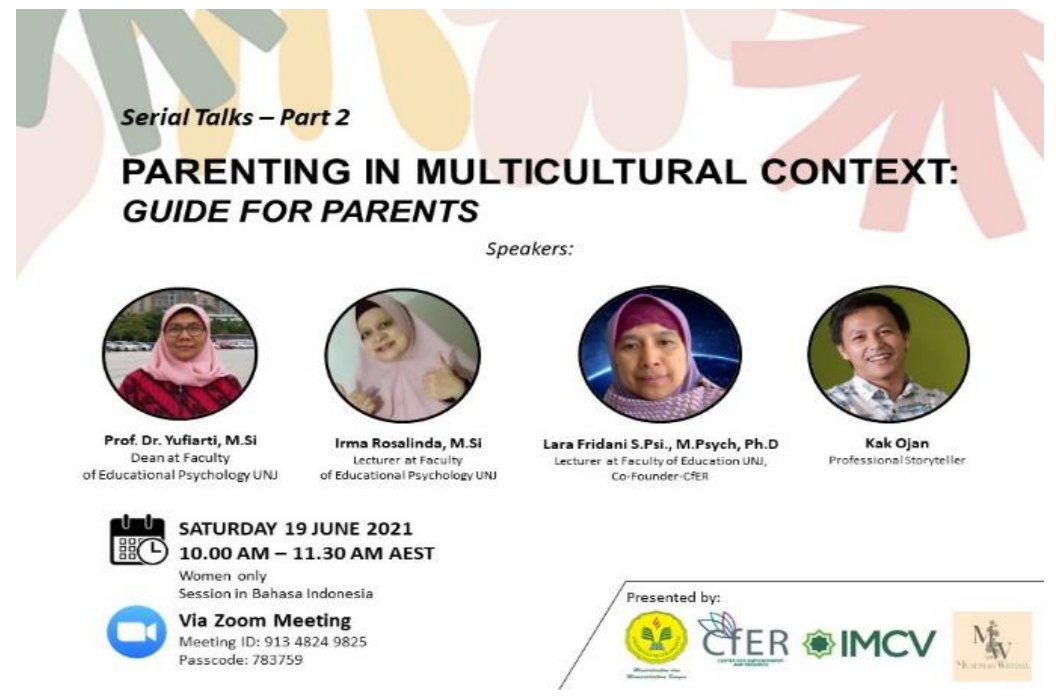

Figure 2. Implementation

The activities communities services have already done since Junne 2021 by zoom. Some of women who stay in Australia follow this activities as 40 participation. The activities of communities services include 1) preparation, 2) implementation and 3) evaluation. The preparation, The preparation include meeting with Cfer organization, IMCV and made sosialization if this activities, such bellow.

\section{Implementation}

The community services doing well such Focus Discussion, counseling and evaluation. The activities implemented by zoom. The participation as 31 member include women who stay in Australia and syudents and lecturer in Jakarta State Universitas. The participation mostly active and we make break out room each activities for more indeep discussion and counceling.

The meeting implement in 12 June 2021 focus on identification in he problems faced by Indonesian women living in Australia are very complex, starting with the goal of going to Australia, mobility, educating their children in different cultures to dealing with children's problems and themselves. 


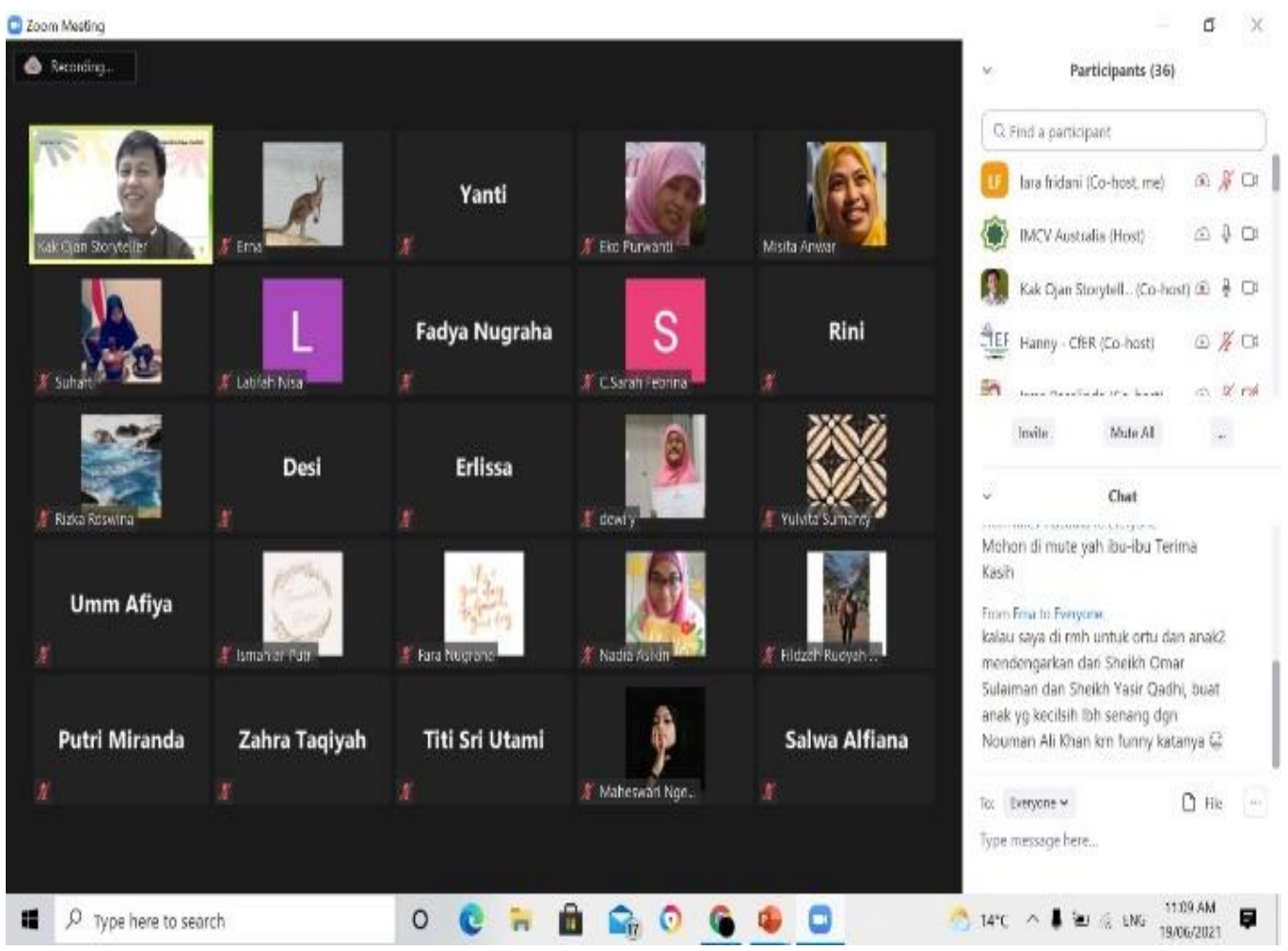

Figure 3. Meeting

\section{CLOSING}

The activities doing well such Focus Discussion, counseling and evaluation. Based on the result of instrumen the mothers interest on the subject matter. They are sutiesfied of this activities. They need this activities again for other subject such as cooking theme.

\section{REFERENCES}

Aydın, H. (2013). Dünya'da ve Türkiye'de Çokkültürlü Eğitim Tartışmaları ve Uygulamaları. Ankara: Nobel Yayınları,
Banks, J, A., \& Banks, C .A .M. (2007). Multicultural education: Issues and perspectives (6th ed.). Hoboken, NJ: Wiley.

Banks, J, A., \& Banks, C .A .M. (2010). Approaches to multicultural curriculum reform. In J.A. Banks \& C. A. Banks (Eds.) Multicultural Education: Issues and Perspectives, 7th Edition Danvers, MA: John Wiley \& Sons. 233-254 May, Stephen dan Sleeter, Christine E. Tim editor. (2010) Critical Multiculturalism: Theory and Praxis, London: Routledge. 